\title{
The Use of Politeness Principle in Teachers' Directive Speech Acts on Teaching and Learning Process at SMA Negeri 5 Merangin Jambi Province
}

\author{
Tumiyar Manulang, Ermanto, Ngusman Abdul Manaf \\ Postgraduate State University of Padang \\ tumiyar07manulang@gmaill.com
}

\begin{abstract}
This study was aimed to (1) explain the type of teacher's directive speech acts, (2) the context of the situation in the teacher's directive speech acts, and (3) the principle of politeness in teachers' directive speech acts on teaching and learning process at SMA Negeri 5 Merangin Jambi Province. Data in the form of speech acts directive teachers collected by way of recorded and observed. The result of the research showed that 1) the type of speech act directive done by the teacher is asking, pleading, demanding, suggesting and challenging, (2) Situation context in speech acts teacher directive are grouped into four, (a) situation context, insensitive topic and noisy atmosphere $(-S,+R) ;(b)$ situation context, topic insensitive and not noisy atmosphere $(-S,-R)$; (c) situation context of sensitive topic and noisy atmosphere $(+S,+R)$; and $(d)$ situation context, sensitive topics and not noisy atmosphere $(+S,-R)$. (3) the principle of politeness that teachers use is the tact maxim, aprobation maxim, agreement maxim, and sympath maxim.
\end{abstract}

Keywords-act directive speech; context; politeness

\section{INTRODUCTION}

Speech acts in learning process is a communication between teachers and students to establish an interaction. One of the dominant speech acts used in learning is the directive speech act. The purpose of teachers' directive speech acts in learning is to explain the material, invite and attract students' attention to the material that is being taught, increase the creativity of students, provide motivation, suggestions and commands to students. As a teacher, it is hoped that through the directive speech acts which is spoken in the classroom can help the students' understanding in getting the meaning or ideas briefly, clearly, organized, and interesting. Thus, teachers should be given a speech in the classroom to encourage students to participate in learning activities. Besides, students as participants in learning activities are expected to respond to speech acts delivered by the teacher. This is necessary in order to realize the cooperation between teachers and students in communicating.

One factor that determines the success of learning in the class is the ability of teachers in giving the speech acts. Therefore, teachers are required to be able to choose the type of directive speech act that is in accordance with the context, and the principle of politeness in speaking. Selection of the directive speech acts, the context of using it and principle of politeness in speech acts done by teachers in the classroom is aimed to create a smooth communication relationship. This will have an impact on the quality and clarity of messages that teachers will convey to students, thereby resulting in maximum communication. Some studies have proven that in the learning process, the teachers should be able to speak with politeness principle while interacting with students in the classroom. These types of research have been done by Bacha, Bahous, and Dial (2012), Merdana, Seken, \& N (2013), and Rahardini \& Suwarna (2014).

Teachers in learning activities should be able to create a sense of familiarity and fun towards students through acts of speech that he did. In the process of teaching and learning, teacher can use possible humor (joke) which is positive to students. The nuances of humor can throw away the exhaustion and saturation of students, so that students feel affectionate, happy and familiar with the teacher. This situation makes students successful in learning activities. Both in speaking, as an example of teachers are required to speak the word well and fun with the way teachers should avoid the words of the vile and dirty (Ramayulis, 2012, p. 19-20).

The act of directive speech that occurs in the learning involves the teacher as the speaker and the student as the speech partner. Learning activities should consider the types of speech acts used in a particular context and also should consider the principle of politeness in speaking. The use of the politeness principl in teachers' directive speach acts speech on learning in the classroom will have an impact for the students, either positive or negative. The teachers' directive speech acts in learning at SMA Negeri 5 Merangin Jambi Province face some problems. First, students often do not respond the teachers' directive speech acts, such as when the teacher asks students to answer questions, but the students do not answer it. Secondly, when the teacher begs the students to be quiet but the students remain noisy. These 
kinds of problems are frequent and repetitive because the teacher do not choose the type of directive speech acts , context, and the principle of politeness in speaking correctly. Therefore, the aim of this study is to explain the type of teachers' directive speech acts; the situation of using directive speech acts; and the principle of politeness on teaching and learning process at SMA Negeri 5 Merangin Jambi Province.

\section{METHODS}

This research was a qualitative research that used descriptive method. According to Moleong (Moleong, 2010, p. 6) qualitative research is a research that intends to understand about what subjects experienced such as behavior, perception, motivation, action and others, holistically and how the description in the form of words and language, on a special context that is natural and by utilizing various scientific methods. The data of this research was in the form of teachers' directive speech acts which was contained in the recording of speech acts done by the teacher to the students in the learning process in class XI IPS 1, XI IPS 2, XII IPS 1, XII2, XII IPA 1, and XII IPA 2. Source research data were teachers who perform speech acts against students in the classroom at SMA Negeri 5 Merangin Jambi Province. This research was conducted at SMA Negeri 5 Merangin which is located at Jalan Perintis No.12 Desa Meranti, Renah Pamenang Subdistrict, Merangi District, Jambi Province.

Instruments in this study were researchers who directly collect data. This was in line with the opinion (Sugiyono, 2012, p. 60) stated that the researcher as a key instrument because the researcher functions is to set the focus of research, select data sources, collect data, identify data, classify data, analyze data and make conclusions. Auxiliary instruments in this study, namely Sony Voice Recorder as a voice recording device, field notes and interviews of teachers and students.

Data collection techniques were basic techniques and advanced techniques. Sudaryanto (1993, p. 133), explained that the simak method has two techniques namely basic techniques and advanced techniques. The basic technique used was tapping technique and advanced technique that is technique of free libat cakap (SBLC), and record. The basic technique in the simak method was called tapping technique. Techniques of tapping in this research was realized by way of recording the ongoing events in learning. When doing the recording the researcher did not tell the research subject that the learning activity is being recorded, this was for the teacher can speak naturally without being engineered. Data were analyzed by step of: (a) identifying teachers' directive speech acts; (b) classifying the directive speech acts; (c) interpreting data based on the focus of the problem; (d) present the research result in the form of research report; and (e) make inferences.

\section{FINDING AND DISCUSSION}

The speech directive of teachers was found as many as 616 speeches of eleven speech events that occurred in the lesson in SMA Negeri 5 Merangin Jambi Province. This study found: first, five types of speech actors directive done by the teacher, namely (1) asking, as many as 340 speeches; (2) to pleading 5 speeches; (3) demanding 88 speeches; (4) suggesting a total of 62 speeches; and (5) challenging as many as 121 speeches. Second, the context of the situation in the speech act directive there are four, namely (1) the context of insensitive topic speech situations and noise atmosphere (-S, + R) as much as 225; (2) the context of the topic speech situation is insensitive and not noisy atmosphere (-S, -R) as much as 246; (3) situational context of sensitive topic topics and noisy atmosphere $(+\mathrm{S},+\mathrm{R})$ as much as 119; and (4) situational context of sensitive topic and not noisy atmosphere (+ S, -R) as much as 26 . (3) principle of politeness used by teacher there are four that is, (1) tact maxim as much as 337 ; (2) aprobation maxim as much as 6; (3) maxim of agreement as much as 210; and sympath maxim 63 as much as. The three research results are explained as follows.

\section{Type of Teachers' Directive Speech Acts in Teaching and Learning Process at SMA Negeri 5 Merangin Jambi Province.}

The results of the study found that there were five types of speech acts in the directive of the teacher in learning in the 5 Merangin state high school in Jambi Province. The five types of speech acts are, (1) directive speech acts asking; (2) directive speech acts pleading; (3) directive speech acts demanding; (4) directive speech acts suggest; and (5) directive speech acts challenging. The following are described the five types of directive speech acts.

\subsubsection{Directive Speech Acts Asking}

Asking directive speech acts is dominant speech acts used by teachers on learning process. Speech acts are used by the teacher to instruct students to answer questions, ask questions, be quiet, do assignments, and work with students. The use of speech act is shown in the following example.

"Igusti, bahasa apa yang kita gunakan dalam surat niaga!"

'Igusti, what language do we use in commercial letters!'

The above speech acts as an example of the use of speech acts that tend to use directive speech acts asking which is the teacher in learning Indonesian. The speech occurs when the teacher is explaining the material, then the teacher asks the students to answer the questions conveyed by the teacher. 


\subsubsection{Directive Speech Acts Pleading}

Pleading directive speech acts is types of directive speech acts that is rarely used by the teachers in teaching and learning process at SMA Negeri 5 Merangin, Jambi Province. Examples of the use of pleading directive speech acts by the teacher in learning can be seen in the following example.

"Tolong diperhatikan ini sama-sama"

,Attention please ${ }^{\text {ee }}$

The speech act above is an example of the use of directive speech acts that tend to use directive speech acts. The speech act is the utterance spoken by Ne's teacher, the Indonesian language subject teacher. These speech acts occur when the teacher is explaining the material that will appear during the upcoming UN exam. The teacher asks students to really pay attention to the material, because such material must always appear from year to year during the national exam. The teacher's application aimed to make students really pay attention to the teacher's explanation about the materials for the National Examination so that the students when the National Examination does not experience difficulties in answering the questions.

\subsubsection{Directive Speech Acts Demanding}

Directive speech acts demand a speech act that is done by the teacher with the aim of requiring students to carry out the intended speech intended by the teacher. Examples of the use of demanding directive speech acts by the teacher in learning can be seen in the following example.

"Yang diminta apa? Kalimat pembuat surat lamaran pekerjaaan sesuai dengan iklan lowongan pekerjaan tersebut.

Kenapa Angge bisa salah jawabannya itu!"

„What is being asked? Sentence of the job application letter corresponding that is appropriate with the job vacancy advertisement. Why Angge writes the wrong answer! !e $^{\text {e }}$

The speech acts above are one example of the use of directive demanding speech acts conducted by teachers in learning in SMA Negeri 5 Merangin Jambi Province. This statement is a speech spoken by Ne's teacher as a teacher in Indonesian language lessons. Speech occurs when teachers and students discuss the material. The teacher demands a student named Angge to explain the cause of the wrong answer. Student answers should not be wrong anymore, because this problem has often been discussed. However, in reality students are still wrong in answering the question.

\subsubsection{Directive Speech Acts Suggest}

The directive speech acts with the type of suggests can be seen in the following example.

"Coba kalian jangan ngomong sendiri-sendiri pasti denger. Ini ngomong sendiri-sendiri bagaimana mau denger"

„Do not talk each other. How could you hear it if you still talk each other"

The above speech acts is a suggestion speech acts of what Na teachers do in teaching Sociology. The act of speech occurs when the student is explaining the material but the other students complains because they can not clearly listen to the student's explanation. This speech is aimed to giving advises to the students to be silence, so that all students can listen to explanations submitted by student who is explaining the material.

\subsubsection{Directive Speech Acts Challenging}

This kind of directive speech acts is done by the teacher in the form of speech as seen in the following example.

"Program yang dikemukakan oleh UKS menjaga kebersihan dan sebagainya. Terus apa lagi!"

„The programs proposed by UKS maintain cleanliness and so on. Then, what else!e

The speech acts as a challenging directive speech acts done by Na teachers in sociology subject. Such speech acts occurs when the teacher explains the material about the resusialisation. The teacher challenges the students to put forward other examples.

\section{Principle of Politeness in Teaching and Learning Process at SMA Negeri 5 Merangin Jambi Province.}

The principle of politeness in learning at SMA Negeri 5 Merangin Jambi Province grouped into four, namely (a) maxim of tact; (b) aprobation Maxim; (c) maxim of agreement; and (d) maxim of inference. Any maxim found in this study will be described as follows.

\subsubsection{Maxim Tact}

Maxim of tact is the maxim that prioritizes the tact of the language. The participants in this maxim should adhere to the principle of always reducing their own profitability and maximizing profit for others in the activity of speech (Lecch, 1993, p. 205). Maxim of tact tends to be used in directive speech acts, in context (-S, + R), (-S, -R), (+ S, + R), and $(+\mathrm{S},-\mathrm{R})$; challenging in context $(-\mathrm{S},-\mathrm{R})$, and $(+\mathrm{S},+\mathrm{R})$; invoke in context $(-\mathrm{S},+\mathrm{R})$, suggest in context $(-\mathrm{S},+\mathrm{R}),(-$ $\mathrm{S},-\mathrm{R})$, and $(+\mathrm{S},+\mathrm{R})$; and demands in the context of $(-\mathrm{S},+\mathrm{R}),(-\mathrm{S},-\mathrm{R}),(+\mathrm{S},+\mathrm{R})$, and $(+\mathrm{S},-\mathrm{R})$.

Examples of maximized use of tact can be seen in the following examples. 


\section{"Lihat punya kamu aslinya!”}

„Can I see yours!ee

The utterance above is an example of tact maxim tended to be used in speech acts enjoined in the context of speech situations (-SR). This speech is aimed to instruct students to show their work to the teacher. In this example the teacher maximizes the use of tact, this maxim will get positive response for students. Students do what the teacher says, the students show their work to the teacher. The use of tact maxim is aimed to get positive and negative response either verbally or non verbal.

"Iya A masalahnya iya tolong dijelaskan!"

„Yes $\mathrm{A}$ is the problem, please explain about it!e

The above speech acts as an example of maxim of tact tended to be used in the context of speech situations (-S, + $\mathrm{R})$. This speech act is done by the teacher to ask students to give their explanation of the answers given previously. The use of the maxim gives the impact of a positive verbal response that students explain the material.

"Ingat, jalan tidak boleh disingkat harus ditulis penuh. Nah, ingat itu, nanti masih juga salah."

„Remember, the adresses should not be abbreviated to be full written. Well, remember that, don't make a mistake again $^{\text {ee }}$

The speech acts above is an example of maximized use of tact, tends to be used in the context (-S, -R). Speech acts are done by the teacher to advise students to remember and do not forget that in the writing of the addresses should not be abbreviated. Teachers maximize the maxim of tact by reminding students not to be wrong in writing addresses. The marker for maximizing the use of tact in the speech is the word "Well, remember that, don't make a mistake again". The use of this maxim in the speech gives the effect of non-verbal negative responses ie students just silent.

"Di tanya malah nanya, ke sekolah niat mau belajar apa mau main."

„I asked you but you remain to ask me, what is exactly your purpose when you go to schoole

This speech acts is an example of tact, tends to be used in acts of defiant directive in the context of speech situations $(+\mathrm{S},+\mathrm{R})$. The purpose of the teacher's speech is to challenge the questioned students, but the students do not answer it. Students are joking each other. The use of this maxim gives the effect of a verbal positive response, the students are just silent.

"Nah, siapkan catatan yang lainnya, kalau tidak saya suruh keluar nanti ditanyain dak bisa."

„Well, prepare another note, you have to answer my question later ${ }^{\text {ee }}$

This speech acts as an example of maximizing the use of tact that tends to be used in demanding speech acts in the context of speech situations $(+\mathrm{S},-\mathrm{R})$. The speech acts are done by the teacher to demand the student to note the material described by the teacher. The use of these maxims gives a positive verbal impact that students answer "Yes" and then the students are seen preparing notes and stop playing.

\subsubsection{Aprobation Maxim}

Maxim of Aprobation is an attempt to make the other people's similarities as little as possible and Aprobationothers as much as possible (Lecch, 1993: 205). Maximized Aprobation tends to be used in action with the context of the situation $(+\mathrm{S},+\mathrm{R})$; challenging with context $(-\mathrm{S},+\mathrm{R})$; suggest and demanding with context $(+\mathrm{S},+\mathrm{R})$.

An example of using maxim of aprobationcan be seen in the following example.

"Hai Ujang mikir dulu baru ngomong!"

„Hi Ujang think it over before speaking! ${ }^{\text {ee }}$

The speech acts above is example of violations of maximized use of aprobation which tend to be used in acts of speech directive in the context of speech situations $(+S,+R)$. The teacher has committed a maximal offense of aprobation because the teacher has enlarged the criticism for the students. The marker of maximal Aprobation violation is marked by the "think it over!" The use of the maxim of Aprobation in this speech gives a negative impact verbal and non verbal, ie students become noisy.

"Yang lain diam! Kamu orang, sapi orang sapi"

„Look at others, they are remain silence! But you acts like a cow ${ }^{\text {ee }}$

This speech acts is an examples of maximized use of aprobation which tend to be used in in the context of speech situations $(+\mathrm{S},+\mathrm{R})$. The act of the speech is using a maximal Aprobation violation. This tutorial is done by the teacher to demand the students to be silent and pay attention to the teacher's explanation. This utterance does not obey the maxim of Aprobation because of the saying "But you acts like a cow", this kind of speech is an effort to enlarge criticism for students. Speech that violates the principle of Aprobation gives the impact of non verbal and verbal negative responses that students laugh at teachers, whispering and do not pay attention to the teacher, even some other students banging the table while laughing.

"Inggat saja itu pengkoreksian temannya. Asalkan Anda jujur Anda selamat."

„Remember that, it was your friend's correction. Make sure that you are honest the you will be safe."

The speech acts above as an example of the use of maxims of Aprobation which tend to be used in acts of speech in the context $(+\mathrm{S},+\mathrm{R})$. Speech acts is aimed to encourage students to be honest in correcting and providing value to the 
results of correction. The teacher maximizes the maxim of Aprobationby giving students confidence that the teacher believes his students have honesty in terms of assigning value to the correction of the questions. The marker of maximized use of Aprobation in the speech is the word "Make sure that you are honest the you will be safe". The use of the Aprobation provides a negative verbal impact that students talk with other students about questions and discuss about the tasks they have examined.

"Komik itu apo, coba apo tahu dak kamu!"

„What is Komik, don't you know that!ee

The speech acts above are examples of the use of maximized Aprobation which tend to be used in the context of speech situations $(-\mathrm{S},+\mathrm{R})$. It is aimed to challeng the students to express opinions, however teachers have minimized the maxim of Aprobationto students. The marker of maximal Aprobation violation is in the words "don't you know that!". Violation of the use of Aprobation maxim gives negative non-verbal effects of students laughing and not paying attention to teachers.

\subsubsection{Maxim Agreement}

The maxim agreement emphasizes the speakers in order to foster a match or consensus in the narrative (Lecch, 199, p. 206). Maximized agreements tend to be used in acts of directive speech, in the context of $(-S,+R),(-S,-R),(+S,+$ $\mathrm{R})$, and $(+\mathrm{S},-\mathrm{R})$; challenging in the context of $(-\mathrm{S},+\mathrm{R}),(-\mathrm{S},-\mathrm{R}),(+\mathrm{S},+\mathrm{R})$, and $(+\mathrm{S},-\mathrm{R})$; invoke in context $(-\mathrm{S},+\mathrm{R})$, and $(+\mathrm{S},+\mathrm{R})$; suggests in the context of $(-\mathrm{S},+\mathrm{R}),(-\mathrm{S},-\mathrm{R}),(+\mathrm{S},+\mathrm{R})$, and $(+\mathrm{S},-\mathrm{R})$; and demands in the context of $(-$ $\mathrm{S},+\mathrm{R}),(-\mathrm{S},-\mathrm{R}),(+\mathrm{S},+\mathrm{R})$, and $(+\mathrm{S},-\mathrm{R})$.

Examples of agreement maxim can be seen in the following example.

"Sudah semuannya silahkan dikumpul dan siapkan biar pulang!"

„Have you finish? Please collect it together and prepare to go home!e

This speech acts as an example of the use of maxim of agreement which tends to be used in acts of speech directive enjoined, in the context of speech situations $(+\mathrm{S},+\mathrm{R})$. It is aimed to makie an agreement to the students to collect tasks immediately and after that the students are welcomed to go home or the learning process is over.

"Jadi susunlah kalimatnya betul-betul, jadi kalau menggambilnya bagaimana, apakah semuanya diambil?"

,So arrange the sentence correctly, so if you take it, do you take them all? ${ }^{\text {ce }}$

This speech acts as an example of the use of agreement maxim which tends to be used in the context of speech situations (-S, -R). It is aimed to make an agreement with the student, about how to quite the words to be used as the main idea of a paragraph. The use of these maxims gives a positive verbal impact that students say answers.

"Tolong diperhatikan ini sama-sama!"

,Please pay attention to this! $!^{\text {ee }}$

The speech acts above as an example of the use of maxim of agreement which tends to be used in context of speech situations $(-\mathrm{S},+\mathrm{R})$. The teacher asks the students to pay attention to the teacher's explanation and is not preoccupied with the work unrelated to the learning at the time. The use of this maxim gives a positive non-verbal impact that students pay attention to teacher explanations.

"Yok cepet! Masih ada delapan menit, yok cepat!"

„Come on! There's still eight minutes, go go!

This speech acts as an example of the use of maxim of agreement which tends to be used in the context of speech situations $(-\mathrm{S},-\mathrm{R})$. The speech is an utterance of agreement maxim with the goal of reaching agreement with the students to immediately do their work and tell them the time to do it still exist.

\subsubsection{Maxim Sympathy}

At the maxim sympathy, the participants are expected to maximize the sympathy attitude one and another (Lecch, 1993, p. 206). Maxim sympath emphasizes the speakers in order to foster a match or consensus in speaking (Lecch, 1993, p. 206). This kind of maxim tend to be used in $n$ the context of $(-S,+R),(-S,-R),(+S,+R)$, and $(+S,-R)$; challenging in the context of $(-\mathrm{S},+\mathrm{R}),(-\mathrm{S},-\mathrm{R}),(+\mathrm{S},+\mathrm{R})$, and $(+\mathrm{S},-\mathrm{R})$; $(\mathrm{S},+\mathrm{R})$, and $(+\mathrm{S},-\mathrm{R})$, and demands in the context of $(-\mathrm{S},+\mathrm{R}$; suggest in context $(-\mathrm{S},+\mathrm{R} ;(-\mathrm{S},-\mathrm{R}),(+\mathrm{S},+\mathrm{R})$, and $(+\mathrm{S},-\mathrm{R})$.

Examples sympath maxim used can be seen in the following example.

"Ya, tolonglah ini untuk diri sendiri, Jangan terbuai dengan impian-impian."

„Yes, do it for yourself, Do not be lulled by dreams."

The mentioned acts above is the maxim use of the sympath which tends to be used in suggestion speech acts, in the context of speech situations (-SR). This kind of speech acts, the teacher asks the students to keep paying attention to the explanation given by the teacher because of the explanation is necessary for the students. The teacher markers maximize the word "do it for yourself". The use of the maxim sympath gives negative non-verbal effects that the students only pause for a while.

"Masih ada waktu banyak, buat contoh sama penjelasannya lima menit selesai itu!"

„We still have time, please make the example with the explanation in five minutes!e 
This speech acts is the example of the use sympath maxim which tend to be used in the context of speech situations $(-S+R)$. The speech acts are done by the teacher to encourage the students to take advantage of the remaining time to do the tasks assigned by the teacher. In the speech the teacher uses the maxim sympath by encouraging students to do the task. The use of maxim sympath the speech gives a negative impact verbal that students ask other students, students should do the task individually instead of asking his friends.

\section{CONCLUSION}

Based on the results of research and discussion about the use of politeness principles in teachers' speech acts on teaching and learning process at SMA Negeri 5 Merangin Jambi Province, it can be concluded that the type of directive speech that uses frequently by the teachers in learning is to ask, challenge, demand, suggest, and request. The context of speech situations in the directive speech act are, namely (1) context of speech situation, insensitive topic and noisy atmospehere $(-\mathrm{S},+\mathrm{R})$; (2) context of speech situation, insensitive topic and not noisy atmosphere (-S, -R); (3) context of speech situations, sensitive topics and noisy atmosphere $(+\mathrm{S},+\mathrm{R})$; (4) context of speech situation, sensitive topic and not noisy atmosphere ( $+\mathrm{S}$, -R). Principle of politeness, namely (1) maxim tact; (2) the maxim aprobation; (3) the agreement; and (4) the maxim sympath. Based on the result of the research, it can be expressed some suggestions related to the research objectives that is, (1) the teacher is able to collaborate the five types of speech acts in the learning so that the learning objectives are achieved and the learning atmosphere in the class becomes more fun for the students, so the students become active; (2) the teacher avoids the mistake in using politeness maxim so they create a polite speech in the learning process as a marker that the teacher is competent in personality.

\section{References}

Bacha. N, N., Bahous. R., \& Diad. R, L. (2012). Gender and politiness in a foreign language academic context. International Journal of English Linguistics, 2 (1), 79-96. Doi:10.5539/ijel.v2n1p79.

Leech, G. (1993). Prinsip-prinsip pragmatik. Terjemahan M.D.D.Oka. Jakarta: UI Press.

Merdana, K, S., \& N. A, J, P. (2013). An analysis of speech acts produced by elementary school teachers and students to facilitate teaching and learning at sdn 10 pringgasela east lombok. e-Jurnal Program Pascasarjana Universitas Pendidikan Ganesha, 1, . Universitas Ganesha.

Moleong, L. (2010). Metodologi penelitian kualitatif. Bandung: Remaja Rosdakarya Offset

Rahardini. A, A., \& Suwarna. (2014). Kesantunan berbahasa dalam interaksi pembelajaran bahasa jawa di smp $n 1$ banyumas. Jurnal Ling Tera, 1(2), 136-144.

Ramayulis. (2012). Profesi \& etika keguruan. Jakarta: Radar Jaya Ofset

Sudaryanto. (1993). Metode dan aneka teknik analisis bahasa. Yogyakarta: Duta Wacana University Pers.

Sugiyono. (2012). Memahami penelitian kualitatif. Bandung: Alfabeta. 